Olivera Ilić

Arheološki institut Beograd

UDK 904:27-524(398)"03/06"

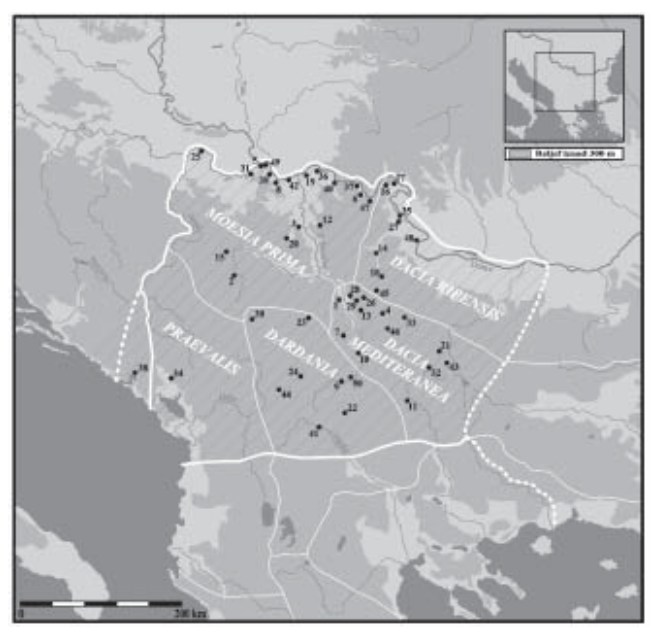

\title{
RANOHRIŠĆANSKI IMPORT NA TERITORIJI SEVERNOG ILIRIKA U PERIODU OD IV DO POČETKA VII VEKA
}

\begin{abstract}
ABSTRAKT
U radu su prezentovani ranohrišćanski predmeti koji su importovani iz različitih delova kasnorimskog Carstva. Najveći broj potiče sa istoka: Male Azije, Sirije ili Egipta, dok je manji broj predmeta izrađivan u nekom od zapadnih radioničkih centara. Proizvodi poreklom iz Male Azije, Sirije, Palestine i Egipta dobavljani su Istočnim pomorskim putem, preko Egeja, a predmeti koji su izrađivani u Italiji ili Dalmaciji pristizali su Zapadnim putem, najčešće preko Jadranskog mora.
\end{abstract}

\section{KLJUČNE REČI: RANOHRIŠĆANSKI PERIOD, LITURGIJSKI PREDMETI, IMPORT, SEVERNI ILIRIK}

U razvoju autohtonog stanovništva u oblasti centralnog Balkana, hrišćanstvo je imalo značajnu i ponekad odlučujuću ulogu. Nakon Milanskog edikta 313. godine nova religija je prihvaćena u Rimskom carstvu, postajući nešto kasnije u vreme Gracijana i Teodosija I (379. i 383. god.) državna religija Carstva. Crkvena organizacija u važnijim gradskim središtima u provincijama: Moesia Prima, Dardania, Praevalis, Dacia Ripensis i Dacia Medierranea, omogućila je širenje hrišćanstva u oblasti južno od Dunava i Save.

Iako su istraživanja u oblasti ranohrišćanske arheologije u Srbiji, započela još krajem XIX veka, tek su poslednjih decenija postignuti značajniji rezultati. ${ }^{1}$ Istraživane su veće urbane aglomeracije,

1. Evans 1883; Валтровић 1886, 70-71; Валтровић 1891a, 130-142; Валтровић 1891б, 109-130; Јеремић,
(Sirmium, Singidunum, Viminacium, Romuliana, Naissus, Ulpiana, Aquae, Remesina etc.), kao i fortifikacije na Dunavskom limesu, ali i dublje u unutrašnjosti. ${ }^{2}$ Nažalost, nemoguće je u ovom kratkom prilogu prikazati sve što je istraženo do sada, tako da je nužno izvrštiti selekciju prikupljenog materijala, koji je ponekad loše protumačen ili publikovan u domaćim časopisima nedovoljno poznatim naučnicima iz drugih zemalja (karta 1).

Arheološki materijal sa istraživane teritorije ukazuje na nekoliko bitnih činjenica:

- pre svega na centre i oblasti odakle se

2004, 43-75; Јеремић 2006, 115-131.

2. Do sada je pronađeno oko 260 predmeta na prostoru Srbije i Crne Gore koji se mogu opredeliti kao ranohrišćanski prema svojoj funkciji ili dekorativnom sadržaju. 
hrišćanstvo širilo na prostoru severnog Ilirika. Novija arheološka istraživanja donela su na svetlost dana čitav niz ranohrišćanskih nalaza izrađivanih u radionicama koje potiču iz različitih delova Carstva. Kao rezultat brojnih trgovačkih veza koje su postojale unutar Rimskog carstva oni su importom stizali i u oblast Centralnog Balkana. Njihova relativna brojnost na prostoru severnog Ilirika ukazuje na već znatan stepen hristijanizacije na ovom prostoru u vremenskom periodu od IV do početka VII veka.

U kategoriju ranohrišćanskog importa, najpre

\section{Karta 1: Nalazišta IV - VII veka}

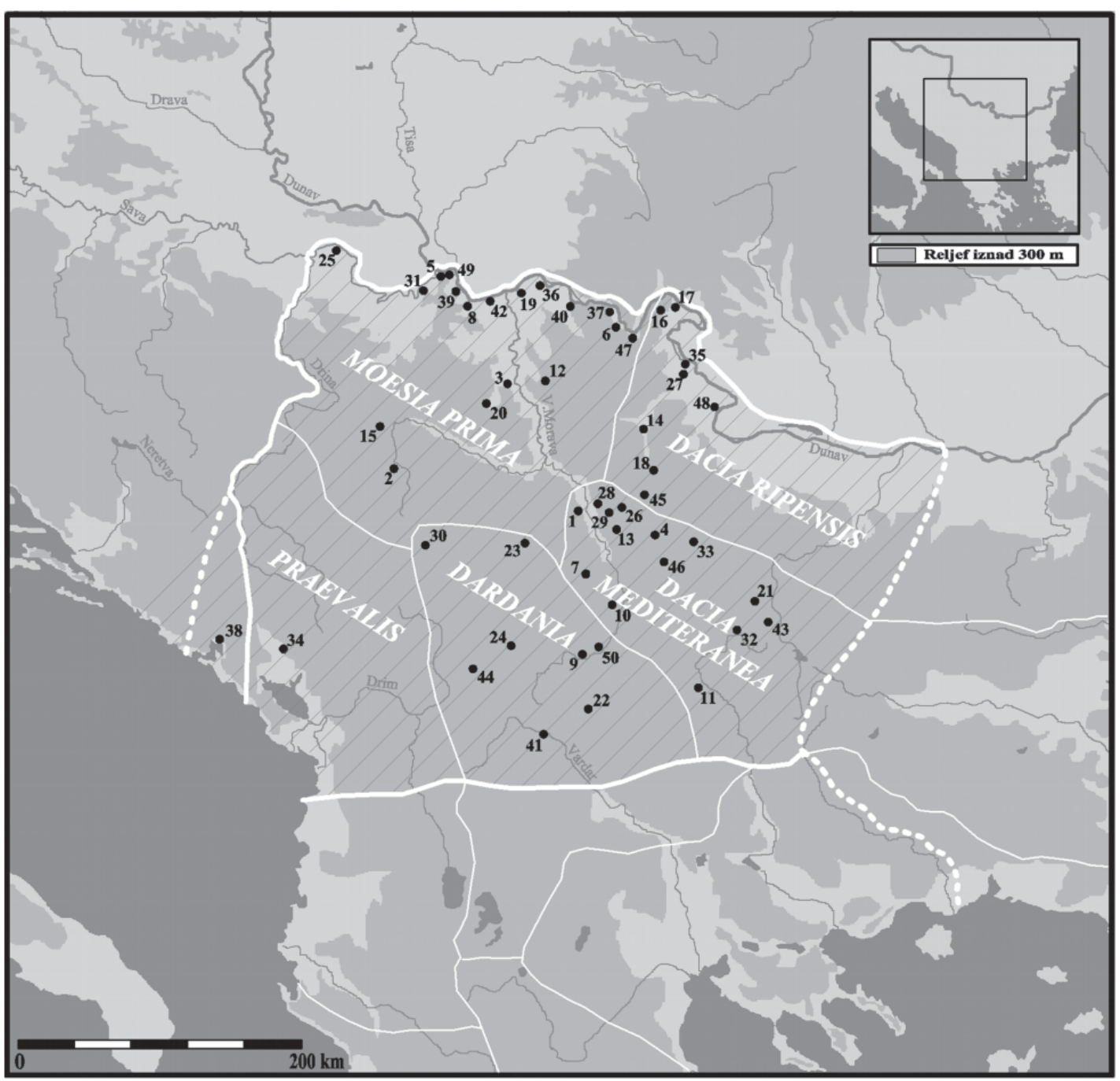

1. Balajnac

2. Baljevac na Ibru

3. Batočina

4. Bela Palanka

5. Beograd

6. Boljetin

7. Bregovina

8. Brestovik

9. Bujanovac

10. Caričin Grad
11. Ćustendil

12. Despotovac

13. Gadžin Han

14. Gamzigrad

15. Gradina na Jelici

16. Hajdučka Vodenica

17. Karataš

18. Knjaževac

19. Kostolac

20. Kragujevac
21. Kostin Brod

22. Kumanovo

23. Kuršumlija

24. Lipljan

25. Mačvanska Mitrovica

26. Manastir

27. Negotin

28. Niš

29. Niška Banja

30. Novi Pazar
31. Ostružnica

32. Pernik

33. Pirot

34. Podgorica

35. Prahovo

36. Ram

37. Ravna

38. Risan

39. Ritopek

40. Saldum
41. Skoplje

42. Smederevo

43. Sofija

44. Suva Reka

45. Svrljig

46. Štrbovac-Babušnica

47. Veliki Gradac

48. Vidin

49. Višnjica

50. Vranje

Prema: Villes et peuplement dans l'Illyricum protobyzantin, Rome 1984. 
treba izdvojiti predmete koji su služili kao liturgijsko posuđe - pehari, zdele, kašike korišćene tokom evharistije, kadionice, relikvijari, ampule itd. Ovi predmeti su na svoj način pokazivali ekonomsko stanje crkvene zajednice kojoj su pripadali i bili su pažljivo skrivani u vremenima napada varvarskih plemena koji su sve češće nadirali na granice Carstva.

Kada govorimo o posuđu namenjenom liturgijskim obredima izuzetan nalaz predstavlja ostava srebrnih posuda iz Viminacijuma koji je postao glavni grad provincije Moesiae Primae krajem III veka. Ostava se sastoji od pet srebrnih pehara na elegantnoj koničnoj stopi (sl. I/1, 2, 3, 4, 5).

Postoje brojni pehari sličnih oblika, koji potiču sa čitavog područja Carstva, koji se na osnovu kontrolnih pečata ili stila izrade najčešće datuju u VI vek. ${ }^{1}$

U poznatoj ostavi iz Kanošija (Canoshio) ${ }^{2} \mathrm{u}$ Italiji nailazimo na slične tipove posuda koje su najverovatnije služile tokom evharističkih obreda. ${ }^{3}$ Pored ovih iz Italije, na pehare iz Viminacijuma podseća i jedna hemisferična zdela na visokoj nozi pronađena u Kartagini, a koja se čuva u Britanskom muzeju u Londonu. ${ }^{4}$ Profilacija stope srebrnog pehara nađenog u blizini Antiohije koji se prema pet identifikovanih pečata datuje u vreme Justinijana I (527-565) veoma je slična stopi viminacijumskih srebrnih posuda. ${ }^{5}$ Danas se čuva u Dumbarton Oaks Collection u Vašingtonu.

Treba pomenuti i fragment srebrnog pehara sa šupljom stubastom stopom koji potiče iz Naissus-

1. Ross 1962, no. 9, pl. X; Dalton 1901, 80, cat. 361; grupa srebrnih predmeta pronađenih u oblasti Hame u severnoj Siriji sadrži pehare, zdele, kutlače i kašike korišćene u liturgijskim radnjama. Nešto ređe su srebrne folije korišćene za pokrivanje crkvenog nameštaja, fenovi i lampe. Oficijelni pečati na ovim predmetima omogućavaju sasvim precizno datovanje. Mundell Mango 1986, 68-73, fig. 1, 2; Cradle of Christianity 2000, 88.

2. Poznata je ostava crkvenih predmeta iz Kanošija ( $\mathrm{Ca}$ noscio) u Italiji u kojoj su pored kašika sa naglašenom hrišćanskom simbolikom (riba, hristogram) pronađene i crkvene posude korišćene tokom evharističkih obreda.

3. Milojčić 1970, 122.

4. Dalton 1901, 80, kat. br. 361.

5. Dodd 1961, 69, No 8. $a$, administrativnog, ekonomskog i kulturnog centra provincije Dacia Mediterranea (sl. II/1). Za ovaj primerak možemo reći da je izrađen izuzetno kvalitetno i da pokazuje visoko umeće majstora poreklom verovatno iz neke od istočnih radionca. Datuje se u IV-V vek.

Iz Viminacijuma takođe potiče mala srebrna posuda u obliku kalotaste zdele na visokoj prstenastoj nozi sa širokim i ravnim obodom oivičenim nizom kuglica koje su zalemljene za ivicu oboda (sl. III/1). Naknadno urezan Hristov monogram sa donje strane vertikalne stope, ukazuje na hrišćansku atribuciju ove zdele. Ovaj tip zdela poznat je kao Schüssel mit Kugelrandverzierung i nalažen je na širokoj teritoriji u poznatim ostavama tog perioda od Britanije do zemalja Sredozemlja. Identičan primerak potiče iz Kerča na Krimu (Panticapaeum) koja se datuje u kasni IV ili početak V veka. ${ }^{6}$

Još jedna zdela istog tipa predstavlja deo ostave srebrnog posuđa u okolini Latakije (Latakiya) u Siriji koja se danas čuva u Umetničkom muzeju u Klivlendu u Ohaju. ${ }^{7}$ Iz Palmire (Palmyra), potiče nalaz sličan prethodno pomenutim, sada $u$ Državnom muzeju u Berlinu. ${ }^{8}$ Kontrolni pečat na ovoj posudi, kao i na još jednoj vrlo bliskoj koja se čuva u Istorijskom muzeju u Moskvi ${ }^{9}$ omogućava precizno datovanje u poslednju četvrtinu IV veka. $\mathrm{Na}$ osnovu svih ovih analogija mogli bismo i zdelu iz Viminacijuma datovati u isti vremenski okvir.

Iako su ove posude nalažene na širokoj teritoriji od istočnog Mediterana do Britanije, one se uglavnom vezuju za istočne radionice kasnorimskog Carstva.

Bogata kolekcija viminacijumskog posuđa sadrži još nekoliko tipova srebrnog posuđa čija je hrišćanska atribucija sasvim izvesna. Među njima izdvajaju se dve plitke zdele horizontalno profilisanog uskog oboda (sl. III/2, 4). Unutrašnja strana je polirana do visokog sjaja, sa naznačenim

6. Spätantike und frühbyzantinische Silbergefässe aus der Staatlichen Ermitage Leningrad, Berlin 1978, 134, Dok. Nr. 2, Abb. 42.

7. Mundell Mango 1998, 214, fig. 12.

8. Dodd 231, cat. 81a.

9. Dodd 231., cat. 82 b. 
središnjim delom oko koga je utisnut krug. $\mathrm{Na}$ spoljašnjoj strani dna, na dva suprotna kraja utisnut je pravougaoni pečat s latinskim krstom. Na obe strane dužeg kraka krsta su utisnuta slova B i Z. Slovo $Z$ je najverovatnije početak aklamacije ZESES, grčki ekvivalent za VIVAS, koji je vrlo čest na ranohrišćanskim natpisima. ${ }^{1}$ Zdele se datuju u VI vek.

Repertoaru kasnoantičkih zdela na visoko postavljenoj koničnoj šupljoj stopi pridružuje se i duboka zdela zadebljanog oboda koja je takođe nađena u Viminacijumu (sl. III/3). Krakovi krsta završavaju slovima C (gore), Z (dole ), A (desno) O (levo). Ovakvi krstovi, monogrami, karakteristični su za Vizantiju VI veka i najčešće sadrže lična imena. ${ }^{2}$ Monogram može da se pročita kao +ZOCA. Reč je o ličnom imenu koje bi moglo da se protumači kao žensko u nominativu ili kao muško u prisvojnom genitivu. ${ }^{3}$ Oba ova imena su česta u kasnoantičkoj onomastici i svojstvena su nižim društvenim slojevima, tako da možemo reći da je njihova pojava na ovom ranohrišćanskom monogramu sasvim uobičajena. ${ }^{4}$

Zdele sličnih oblika sa monogramima u obliku krsta nalažene su u različitim delovima rimskog carstva i uglavnom se vezuju za istočne radionice.

Srebrne kašike predstavljaju važan deo pribora korišćen tokom liturgijskih radnji. Na prostoru severnog Ilirika otkriveno je pet primeraka srebrnih kašika, od kojih četiri gotovo istovetna primerka potiču iz Viminacijuma (sl. IV/1, 2, 3, 4), dok nalaz koji se nešto razlikuje svojim dekorativnim sadržajem potiče iz Gamzigrada (sl. IV/5). Kašike iz Viminacijuma čine deo ostave u kojoj su bile još dve srebrne posude prethodno pomenute (sl. III/2, 4).

Pripadaju tipu Desana prema ostavi pronađenoj u Desani u Italiji. ${ }^{5}$ Karakteristika ovog tipa kašika

1. Diehl 1961, 458; brojni su ranohrišćanski spomenici na kojima je prisutna aklamacija ZESES, odnosno latinski ekvivalent VIVAS.

2. Dodd 1961, 15; monogrami u obliku krsta se pojavljuju od vremena Justinijana I i traju kroz čitav VI vek.

3. Кондић 1994, 66-67.

4. Diehl 1961, 4029.

5. Simoni 1988, 80; ova poznata ostrogotska ostava sadrži je da se na prelazu od recipijenta ka dršci nalazi mali disk dok je drška izdužena i na krajevima zašiljena. Na disku su obično bili urezani različiti hrišćanski simboli ili natpisi. Na sve tri kašike iz Viminacijuma urezan je monogram izveden u ligaturi koji može da se pročita kao AENEAS ili njegova varijanta AENEVS. ${ }^{6}$

Kašika iz Gamzigrada (Romuliana) takođe je izrađena od srebra (sl. IV/5). Za razliku od primeraka iz Viminacijuma dekoracija je izvedena na recipijentu, a sadrži hrišćanski simbol u vidu stilizovanog hristograma izvedenog punciranjem. Monogram se sastoji od preklopljenog grčkog krsta i slova "P" koje je otvoreno. Ovaj tip monogramskog krsta u upotrebi je od druge polovine IV veka i traje do kraja V veka. ${ }^{7}$

Ovi predmeti su od naročite važnosti tokom vršenja evharističkih obreda u crkvi i imaju svojih brojnih bližih i daljih analogija na čitavom prostoru Evrope i Mediterana. Uglavnom su hronološki opredeljene u vremenski period od V do VII veka. ${ }^{8}$

Da pomenemo samo Dumbarton Oaks kolekciju iz Vašingtona koja sadrži sedam izuzetno luksuzno proizvedenih srebrnih kašika sa monogramom na disku koji povezuje recipijent sa drškom. Natpisi na dršci rađeni u nielo tehnici ukazuju na hrišćanski karakter ovih kašika, korišćenih tokom evharističkih obreda. ${ }^{9}$ Naime, imena sadržana u natpisima jasno ukazuju da su u pitanju imena apostola (Toma, Luka, Marko, Petar, Matija, Filip i Pavle) i najverovatnije da je prvobitno broj ovih kašika iznosio dvanaest. M. Ross je ove kašike pripisao radionici u Konstantinopolju i datovao u kasni VI ili početak VII veka. ${ }^{10}$

pored ostalih nalaza i 18 srebrnih kašika od kojih 12 Desana tip. Datuje u period od oko 500 godine do prve polovine VI veka.

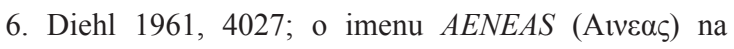
ranohrišćanskim natpisima.

7. Testini 1958, 356.

8. Milojčić 1970, 111- 133; u svojoj obimnoj studiji o srebrnim kašikama, autor je prikazao brojne primerke koji potiču sa čitavog prostora Evrope (396 nalaza) sa svim mogućim kombinacijama dekorativnog sadržaja i natpisa. 9. Mundell Mango 1986, cat. 49-56.

10. Ross 1962, cat. 13, Pl. XVII. 
Kadionice su kao deo bogoslužbenih predmeta imale značajnu ulogu u liturgijskim obredima još u ranohrišćanskom periodu. Sa prostora severnog Ilirika izuzetan nalaz predstavlja bronzana kadionica iz porušene crkve sv. Nedelje u selu Pepeljevcu, nedaleko od Kuršumlije (sl. V/1, 2). Kadionica je loptastog oblika, na kružnoj stopi, bez sačuvanog poklopca. Na centralnom delu trbuha date su u reljefu predstave iz Hristovog života: Blagovesti, Susret Bogorodice i Jelisavete, Rođenje Hristovo, Javljanje pastirima o Hristovom rođenju, Krštenje i Raspeće (sl. VI/1).

Kadionice sličnih oblika i dimenzija, sa sličnim prizorima iz Hristovog života nađene su na velikom broju lokaliteta, kako u oblasti Mediterana tako i dublje u unutrašnjosti evropskog kontinenta. Pronađene su u Egiptu, Siriji, ali isto tako i u istočnoj Turskoj, južnoj Rusiji i Kavkazu, kao i u centralnoj Aziji. ${ }^{11}$ Iako nisu identične, reljefna dekoracija sa predstavama iz Hristovog života je slična kako po kompoziciji, tako i po stilu, ukazujući na taj način na njihovo zajedničko poreklo. Kako je izbor scena više ili manje sličan onima na uljanim ampulama izrađivanim u Svetoj Zemlji, danas je opšte prihvaćena pretpostavka da ovaj tip kadionica takođe može da se uključi u kontekst hodočasničkih umetničkih predmeta poreklom iz Sirije ili Palestine. ${ }^{22}$

Kada govorimo o ovom tipu kadionica, još uvek nema pravog odgovora na pitanje njihove hronološke determinacije. Iako su kadionice ovog tipa vrlo bliske, ipak se dovoljno razlikuju jedna od druge ukazujući na proizvodnju koja je trajala tokom dužeg vremenskog perioda počev od VI veka pa do ranog srednjeg veka. Ikonografija ovih kadionica nije se mnogo menjala tokom ovog perioda, naročito ne na kadionicma pronađenim na prostoru Mediterana koji je već bio pod arabljanskom vlašću od sredine VII veka.

Većina naučnika koji su se bavili ovom problematikom pretpostavljaju da su originalne kadi-

11. Gonosová 1994, 276, nap. 6; do sada je evidentirano 95 nalaza ovog tipa krstionica.

12. Grabar 1958 1/ff. onice vremenom zamenjivane tamo gde je bilo potrebno novim replikama čime se može objasniti veliki broj sačuvanih primeraka. ${ }^{13}$

Nakon VII veka, većinu kadionica ovog tipa karakteriše pojednostavljeni figuralni izraz, koji iako i dalje pod uzorima VI i početka VII veka, gubi punoću izraza idući postepeno ka šematizovanoj predstavi.

I na kraju da se vratimo našoj kadionici iz Pepeljevca kod Kuršumlije. Iako su reljefne predstave dosta bliske vizantijskoj umetnosti VI-VII veka, teško možemo reći da se radi o nalazu koji je izrađen u Svetoj Zemlji, već bi se pre moglo govoriti, na osnovu analognih primeraka, da je u pitanju kopija sirijsko-palestinskih originala. Budući da je veoma slična nekim primercima koji su manje više egipatske provenijencije, možemo je takođe označiti kao egipatski proizvod kasnog VII ili početka VIII veka. ${ }^{14}$

Kadionica iz Gamzigrada (Romuliana), predstavlja deo ostave u kojoj je pored kadionice nađen polijelej, kandelabr i okov u vidu pečurke (sl. VII/1, 2, 3, 4). Kadionica je izrađena od bronze, šestougaonog oblika, jednostavne de-koracije u vidu profilisane osnove i oboda. Postavljena na tri nožice koje završavaju u obliku lavljih šapa. Bila je okačena na tri lanca koji su pri vrhu spojeni karikom u vidu osmice. Kadionice ovog tipa sa sličnim dekorativnim sadržajima nađene su na velikom broju lokaliteta na čitavom prostoru kasnorimskog Carstva iz čega možemo konstatovati da je postojala prilična ujednačenost u njihovoj proizvodnji što, bez sumnje, ukazuje na postojanje izdvojenih proizvodnih centara, najverovatnije u Egiptu, odakle su distribuirane u druge delove Carstva. ${ }^{15}$

Među predmetima koji se takođe vezuju za hrišćanski kult treba pomenuti i relikvijare. Tri

13. Gonosová, Kondoleon, 1994, 277.

14. Gonosová, Kondoleon, 1994, 277; iako je ova kadionica nešto mlađa od predmeta o kojima se govori u radu, smatrala sam da je potrebno pomenuti je budući da predstavlja kopiju primeraka iz VI-VII veka.

15. Stryzgowski 1904, No. 9116, Taf. XXXII; Мано-Зиси 1962, 103, sl. 3. 
srebrna primerka potiču sa teritorije Srbije (sl. VIII/1, 2, 3). Relikvijar iz okoline Niša hronološki se opredeljuju u IV vek (sl. VIII/2) i verovatno je pripadao nekoj kultnoj građevini, crkvi ili memoriji u okolini antičkog Naissus-a na koji izvori upućuju kao grad sa velikim brojem martira koji, nažalost, nisu imenovani niti potvrđeni. Druga dva nalaza iz Romulijane i utvrđenja Gradine na Jelici datuju se u VI vek (sl. VIII/1, 3).

Relikvijari čine značajnu grupu ranohrišćanskih predmeta. Oni su uglavnom ukrašeni različitim hrišćanskim prizorima ili simbolima, a često ćemo naići i na natpise sa imenima apostola ili svetaca, kao što je slučaj sa relikvijarom iz Gradine na Jelici - $S(a n) c(t) i$ Petri, $S(a n) c(t) i$ Pauli $+S($ an $) c(t) i$ Iohanni.

Dosadašnja istraživanja su pokazala da većinu relikvijara oblika rimskih sarkofaga, treba pripisati istočnomediteranskom prozvodnom krugu. Najčešće su pronalaženi na području jugoistočne Evrope i Male Azije i datuju se uglavnom u vreme od IV do VI veka. ${ }^{1}$ Posebno treba istaći područje susedne Bugarske na čijoj teritoriji je pronađeno do sada ukupno 35 relikvijara različitih oblika, materijala i načina izrade, tako da predstavlja jedinstveno područje ne samo u jugoistočnom delu Evrope, već i na čitavom mediteranskom prostoru. ${ }^{2}$

U kategoriju predmeta koji su povezani sa hrišćanskm kultom treba uvrstiti i ampule (eulogije). Ovi predmeti, od velikog značaja za religijski život hrišćanskih zajednica u prvim vekovima hrišćanstva, bili su izuzetno dragoceni, budući da do njih nije bilo lako doći.

Sa prostora severnog Ilirika do sada su otkrivena samo dva nalaza (sl. IX/1, 2). Iz Caričinog Grada potiče primerak izrađen od pečene gline koji svojim oblikom i figuralnom predstavom hrišćanske sadržine datom u reljefu ukazuje na maloazijsko radioničko poreklo. ${ }^{3}$

Drugi primerak iz Mačvanske Mitrovice bitno se razlikuje od ampule iz Caričinog grada, kako

1. Buschhausen 1971, 286-315, Taf. C12-C26.

2. Minchev 2003, 1/ff; radi poređenja, samo 12 primeraka je pronađeno u Maloj Aziji uključujući i Konstantinopolj. 3. Metzger 1984, 160. po materjalu od kojeg je izrađena, tako i po svojoj formi i dekoraciji. U pitanju je mala ampula od olova, oblika amfore, sa ornamentikom koja se sastoji od krstova, vegetabilnih i geometrijskih motiva.

Ampule kao specifičan vid predmeta koji stoji u vezi sa hrišćanskim kultom predstavljaju vrlo retke i izuzetne nalaze, budući da svojim ikonografskim sadržajima doprinose novim saznanjima o religijskom verovanju stanovništva u prvim vekovima razvoja hrišćanstva. Izrađivane su u velikim količinama u radionicma koje su podizane u blizini važnih hrišćanskih centara posvećenih kultu: u Palestini, Siriji, Egiptu i Maloj Aziji u periodu od IV do VI veka. ${ }^{4}$ Naša dva primerka svojim ikonografskim sadržajem pripadaju istom proizvodnom krugu i hronološkom okviru.

Sa teritorije Prahova (Aquae), jednom od episkopskih centara u provinciji Dacia Ripensis, potiče stakleno dno rađeno u tehnici fondi d'oro (sl. X/1). ${ }^{5}$ Sačuvani deo kružnog dna, najverovatnije tanjira, sadrži na zlatnoj foliji u središnjem delu urezane predstave muškarca, žene i deteta. Iznad figura teče natpis na latinskom jeziku VIVAS IN DEO. Ovakva pozlaćena stakla svojstvena su zapadnom delu kasnorimskog carstva. Uobičajeno je mišljenje da je najveće, a možda i jedino mesto izrade ovakvih predmeta bio Rim. ${ }^{6} \mathrm{~S}$ druge strane pretpostavlja se da su se u Trijeru, drugom velikom provincijskom središtu proizvodnje stakla izrađivali manji medaljoni i staklena dna. ${ }^{7}$ Procvat ove tehnike vezuje se za period III i IV veka. ${ }^{8}$

Pored gore navedenih predmeta koji su korišćeni u hrišćanskom kultu, postojao je i čitav

4. Grabar 1958, 1/ ff.

5. Danas je još uvek neusaglašena terminologija za pozlaćena staklena dna. Počev od XVII veka ona su nazivana raznim imenima: vetri cimiteriali, fondi d'oro, fonds, dorées, Zwischengoldgläser, Goldgläser, gold glasses, gold-sandwich glasses, gilded glasses. Termin fondi d'oro je danas uglavnom napušten, čak i u zemlji svog porekla, dok se u našoj literaturi ovaj izraz odomaćio, tako da ćemo se u radu i dalje pridržavati uobičajne terminologije.

6. Migotti 2003, 16.

7. Cambi 1976, 141.

8. Cermanović-Kuzmanović 1976, 175-190; Ранков 1983,85 . 
niz predmeta korišćenih u funkciji crkvenog mobilijara, a koji je mogao biti importovan iz različitih delova Carstva kao što su: polikandila, (sl. XI/1, 2, 3) kandelabri, (sl. XII/1, 2) lampe, (sl. XIII/1, 2, 3, 4, 5, 6). Ova vrsta nalaza zastupljena je kako u većim urbanim aglomeracijama, tako i u utvrđenjima na Dunavu i u unutrašnjosti poluostrva. Naročito veliki broj predmeta potiče iz Caričinog Grada (Iustiniana Prima?) što se pored njegovog značaja kao crkvenog središta, odnosno sedišta arhiepiskopije može objasniti i sistematskim istraživanjima ovog lokaliteta koja datiraju još s početka XX veka. Prisustvo crkvenog mobilijara indicira postojanje hrišćanskih hramova u blizini, što je u većini slučajeva i potvrđeno.

Takođe su se trgovačkim putevima iz različitih delova Carstva mogli nabaviti i najrazličitiji predmeti profane namene, a koji su svojim oblikom ili dekorativnim sadržajem ukazivali na hrišćanski karakter. Da pomenemo samo delove nošnje ili nakit: fibule, kopče, ogrlice (sl. XIV), narukvice, minđuše, prstenje itd. Neki od njih su izrađivani od plemenitih metala (zlata ili srebra). Nalaženi su uglavnom u većim urbanim centrima i to naročito primerci luksuznije izrade.

Da bi se pribavili gore pomenuti nalazi, kao i mnogi drugi kultne ili profane namene, bilo je moguće zahvaljujući postojanju trgovačkih puteva koji su povezivali oblast južno od Dunava i Save sa važnim proizvodnim centrima u Maloj Aziji, Srednjem Istoku i Egiptu, a na zapadu sa Dalmacijom i Italijom. Postojala su dva glavna trgovačka puta kojima se razmenjivala najrazličitija roba $u$ periodu od IV do početka VII veka. Istočni pomorski put koji je vodio istočnim delom Mediteranskog mora i Egeja do Soluna, a potom kopnenim putem kroz unutrašnjost Balkanskog poluostrva i Zapadni put koji je išao preko Jadranskog mora, Dalmacije na sever do Panonije (karta 2). ${ }^{9}$

Proizvodi poreklom iz Male Azije, Sirije, Palestine i Egipta dobavljani su Istočnim putem, a predmeti koji su izrađivani u Italiji ili Dalmaciji pristizali su Zapadnim putem. Postojali su i bro- jni proizvodi izrađivani i distribuirani iz centara koji su geografski bili znatno bliže centralnobalkanskom regionu u odnosu na pomenute lokacije. Tu u prvom redu mislimo na najvažnije paleovizantijske centre Carigrad i Solun odakle se roba najčešće kretala trgovačkim putevima kroz Trakiju i Makedoniju.

Na kraju možemo da zaključimo da brojnost i raznolikost importovanog ranohrišćanskog materijala, među kojima su i predmeti korišćeni tokom liturgijskih obreda ukazuju na postojanje brojne i dobro organizovane hrišćanske crkve. Nalazi liturgijskog posuđa, kadionica, relikvijara, posuda za čuvanje svetog ulja, i drugih predmeta pokazuju već razvijen oblik hrišćanskog života. Episkopije Severnog Ilirika su u tom smislu igrale vrlo važnu ulogu. Dovoljno je pomenuti Caričin Grad (Iustiniana Prima?). U ovom gradu Justinijan I (527-565) osnovao je novu arhiepiskopiju koja je postala administrativni i duhovni centar čitavog Ilirika.

Međutim, već početkom VII veka u invaziji ekspanzionističkih plemena sa severoistoka Evrope, pre svega Avara i Slovena, antički svet je bio uništen i veliki urbani centri kao i tvrđave duž Dunavskog limesa, ali i dublje u unutrašnjosti, a samim tim i crkve i druga kultna mesta opljačkani i najčešće spaljeni i srušeni. Time se može objasniti postojanje relativno velikog broja ostava sa skupocenim predmetima koji su bili važni za religijski život prvih hrišćanskih zajednica na prostoru Centralnog Balkana.

9. Teodor 2001, 122. 


\section{RESUME \\ Early Christian Roman \\ Imports in the territory of North Illyricum from $4^{\text {th }}$ to $6^{\text {th }}$ century}

Archaeological material from the territory of Central Balkan, in the Late Roman period North Illyricum, points to several important facts: first of all, the centres and regions from where Christianity extended in this territory. Newer archaeological discoveries have brought to light a series of finds of great importance; some of them made in the workshops coming from various parts of the Late Roman Empire and imported by the people from the provinces of North Illyricum, as a result of the numerous connections with the other parts of Roman Byzantine world.

Among the numerous silver objects used in liturgical ceremonies, of a great interest has been the discovery of liturgical vessels: chalices, bowls, the Eucharist silver spoons, censers, reliquaries, vessels for keeping holy oil, and other objects show an intense Christian life with constant connections to the religious institutions within the territories of the Empire among which the episcopacies of North Illyricum played an important part.

The obtaining of these Christian objects, mentioned above, so as of others, having a different utility, has been possible because of the existance of some old and importante commercial routes which used to link the region south of the river Sava and the Danube with the strong centres of the handycraft wares in Asia Minor, and Middle East, Egypt, and in the West in Italy.

Based on the analogies with the objects made in some centres of the Empire and the spreading over of the types of the imported objects in the

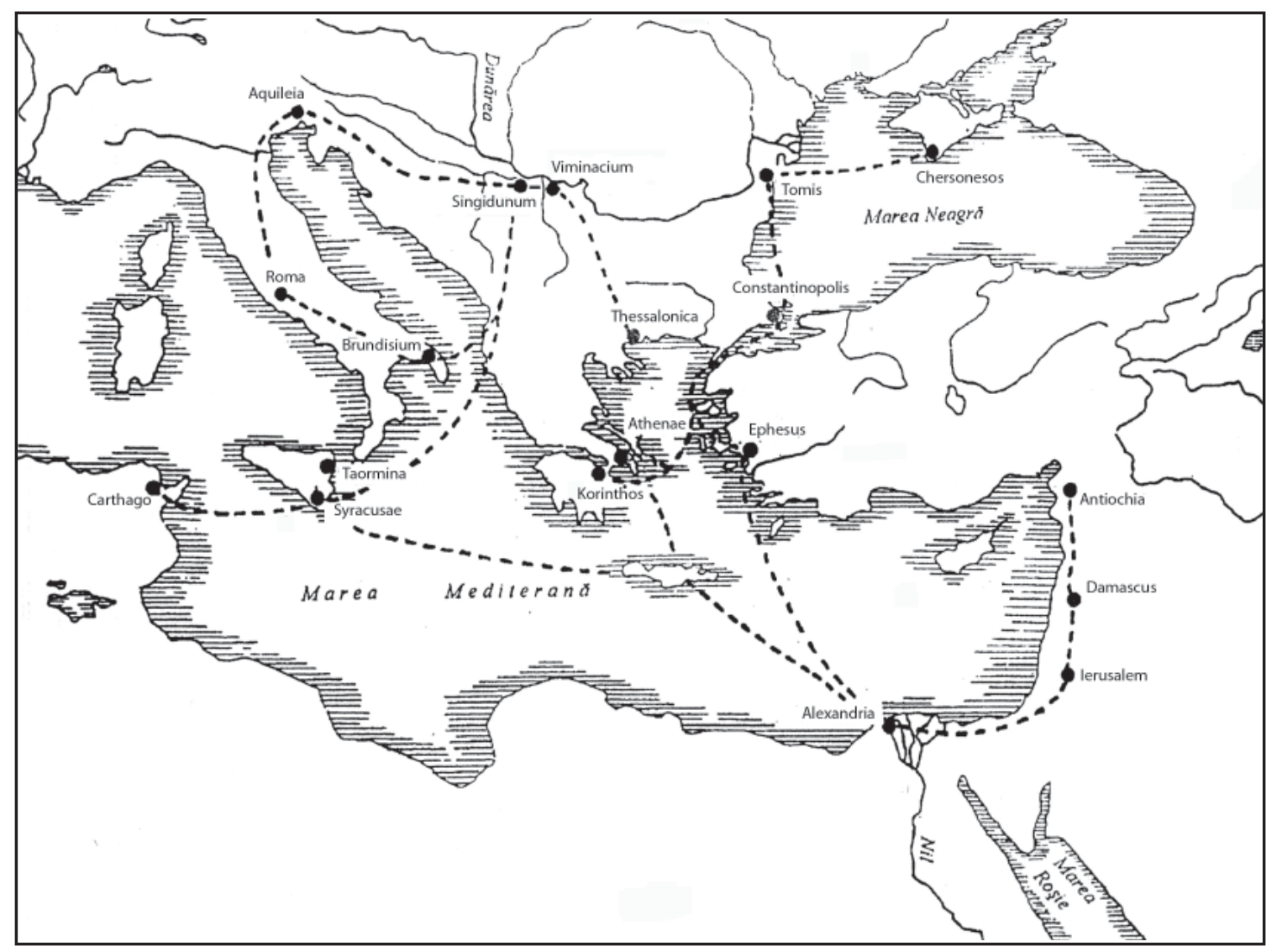

Karta 2. Glavni rimski trgovački putevi, IV-VI vek.

(Prema: Dan Gh. Teodor, Interacademica II-III/2000). 
Central Balkan regions, it is obvious that two main routes of exchanges kept on being used during the period between the $4^{\text {th }}$ and the $6^{\text {th }}$ century; the Eastern one going over the East of the Mediterranean Sea and the Aegean; and the Western one which crossed over the Adriatic Sea, Dalmatia and on the north Pannonia.

A great number and the diversity of the imports of Christian nature among these objects used for performing the religious service prove the existance of numerous and well organised Christian communities.

By the end of that period, at the beginning of $7^{\text {th }}$ century, in the invasion of expansionist tribes from the northeast of Europe, including the Avars and Slavs, the ancient world had been destroyed and the great urban centres, castles along the Roman Limes on the Danube, churches and other cult places had been plundered and in the majority of cases burned out and demolished.

\section{SKRAĆENICE}

AV - Arheološki vestnik, Ljubljana

ZRNM - Zbornik radova Narodnog muzeja

ZRVI - Zbornik radova Vizantološkog instituta

ZRNMČ - Zbornik radova Narodnog muzeja u Čačku

\section{BIBLIOGRAFIJA}

\section{Bénazeth 1992}

D. Bénazeth, L'art du métal au début de l'ère chrétienne, Musée du Louvre, Catalogue du département des antiquities égyptiennes, Paris 1992.

\section{Buschhausen 1971}

H. Buschhausen, Die spätrömischen Metallscrinia und frühchristlichen Reliquiare I, Katalog, Össterr. Akad. d. Wiss., Komiss. für Byzantinistik, Wiener byzantinische Studien IX, Wien 1971.

\section{Cambi 1976}

N. Cambi, Neki kasnoantički predmeti od stakla s figuralnim prikazima u Arheološkom muzeju u Splitu, Arheološki Vestnik XXV, 1976, 139-157.

\section{Cradle of Christianity 2000}

Cradle of Christianity, The Israel Museum, Jerusalem 2000, Eds. Y. Israeli, D. Mevorah, Catalogue of the Exhibition, Jerusalem 2000.

\section{Dalton 1901}

O. M. Dalton, Catalogue of Early Christian antiquities and objects form the Christian East, London 1901.

\section{Diehl 1961}

E. Diehl, Inscriptiones latinae christianae veteres, vol. II, Berolini 1961.

\section{Dodd 1961}

E. C. Dodd, Byzantine Silver Stamps, Washington 1961.

\section{Duval, Jeremić 1984}

N. Duval, M. Jeremić, L'église J à une nef, Caričin Grad I, Collection de l'école française de Rome, Belgrade-Rome 1984, 91-146.

\section{Gonosová, Kondoleon 1994}

A. Gonosová, Ch. Kondoleon, Art of Late Rome and Byzantium, in the Virginia Museum of fine Arts, Virginia Museum of Fine Arts, Richmond, 1994.

\section{Grabar 1958}

A. Grabar, Les Ampoules de Terre Sainte MonzaBobbio, Paris, 1958.

\section{Evans 1883}

A. Evans, Antiquarians Researches in Illyricum IV, Westminster 1883. 


\section{Janković 1983}

Đ. Janković, U sutonu antike, u S. Ćelić (ur.), Gamzigrad kasnoantički carski dvorac, Beograd 1983, 99-119.

\section{Janković 1983a}

Đ. Janković, Ranovizantijski Gamzigrad, u S. Ćelić (ur.), Gamzigrad kasnoantički carski dvorac, Beograd 1983, 120-142.

\section{Janković 1997}

M. Janković, Seoba naroda, u S. Krunić (prir.), Antička bronza Singidunuma, katalog izložbe, Beograd 1997, 305-340

\section{Jeličić 1959}

B. Jeličić, Bronzani žišci u Narodnom muzeju, Zbronik radova Narodnog muzeja II, Beograd 1959, 73-82.

\section{Jeličić 1964}

B. Jeličić, Bronzani kandelabr u Narodnom muzeju u Beogradu, Zbornik Narodnog muzeja IV, Beograd 1964, 151-155.

\section{Јеремић 2004}

М. Јеремић, Култне грађевине хришћанског Сирмијума, Сирмијум и на небу и на земљи, Сремска Митровица 2004, 43-75.

\section{Јеремић 2006}

M. Јеремић, Adolf Hytrek et les premières fouilles archéologiques à Sirmium, Старинар LV, Београд 2006, 115-131.

\section{Kent 1961}

J. P. C. Kent, Comes Sacrarum Largitionum, Ex. in: E. C. Dodd, Byzantine Silver Stamps, Washington 1961, 37-45.

\section{Kondić 1994}

J. Kondić, Ranovizantijsko srebro, u I. Popović (ur.), Antičko srebro u Srbiji, Beograd 1994, 65-67.

\section{Kondić 1995}

J. Kondić, Kasnoantičko i ranovizantijsko srebrno posuđe iz Srbije, u I. Popović, T. Cvjetičanin, B. BorićBrešković (prir.), Radionice i kovnice srebra, Beograd 1995, 181-187.

\section{Kondić, Popović 1977}

V. Kondić, V. Popović, Caričin Grad utvrđeno naselje u vizantijskom Iliriku, Beograd 1977.

\section{Korać 2000}

M. Korać, Slikarstvo grobnica u Viminacijumu, Požarevac 2000.

\section{Ljubinković-Ćorović 1950}

M. Ljubinković-Ćorović, Stara kadionica iz okoline Kuršumlije, Muzeji 5, Beograd 1950, 70-86.

\section{Marjanović-Vujović 1973}

G. Marjanović-Vujović, Dva rana hrišćanska polijeleja iz Narodnog muzeja, Zbornik Narodnog muzeja VII, 1973, 13-23.

\section{Metzger 1973}

C. Metzger, Une ampoule à eulogie du type d' Asie Mineure, Caričin Grad I, Collection de l'école française de Rome, Belgrade-Rome 1984, 158-160.

\section{Migotti 2003}

B. Migotti, Pozlaćena stakla sa Štrbinaca kod Đakova, Đakovo 2003.

\section{Milinković 1986}

M. Milinković, Gradina na Jelici, ZRNMČ XVI, Čačak 1986, 47-60.

\section{Milinković 2002}

M. Milinković, Die Byzantinische Höho-henanlage auf der Jelica in Serbien - Beispiel aus dem Nördlichen Illyricum des 6. Jh., Starinar LI, Beograd 2002, 71-133.

\section{Minić 1980}

D. Minić, Le site d'habitation médiéval de Mačvanska Mitrovica, Sirmium XI Beograd 1980. 
Arheologija i prirodne nauke

\section{Minchev 2003}

A. Minchev, Early Christian Reliquaries from Bulgaria, 4th - 6th Century AD, Varna 2003.

\section{Mundell Mango 1986}

M. Mundell Mango, Silver from Early Byzantium, the Kaper Koraon and Related Treasures, (The Walters Art Gallery), Baltimore 1986.

\section{Popović 2001}

I. Popović, Kasnoantički i ranovizantijski nakit od zlata u Narodnom muzeju u Beogradu, Beograd, 2001.

\section{Popović 1970}

V. Popović, Ranohrišćanska bronzana lampa iz okoline Smedereva, Starinar XX, Beograd 1970, 323330 .

\section{Rankov 1983}

J. Rankov, Kasnoantičko stakleno dno rađeno u tehnici fondi d'oro, Zbornik Narodnog muzeja XI-1, Beograd 1983, 85-89.

\section{Ross 1962}

M. Ross, Catalogue of the Byzantine and Early Mediaeval Antiquities in the Dumbarton Oaks Collection, vol. I, Washington 1962.

\section{Ružić 1994}

M. Ružić, Rimsko staklo u Srbiji, Beograd 1994.

\section{Simoni 1988}

K. Simoni, Srebrna žlica iz Siska, Vjesnik Arheološkog muzeja u Zagrebu XXI, Zagreb 1988, 79-86.

\section{Shukriu 2003}

E. Shukriu, Frühchristliche Lampen aus antiken Provinz Dardania, Mitteilungen zur christlichen Archäologie, Össterr. Akad. d. Wiss., Inst. für klass. Archäol. der Univer. Wien, Band 9, Wien 2003, 19-23.

\section{Strzygowski 1904}

J. Strzygowski, Catalogue du Musée du Caire, Koptische Kunst, Viene 1904.

\section{Tatić-Đurić 1960}

M. Tatić-Đurić, Jedna kasnoantička lampa iz zbirke Narodnog muzeja u Beogradu, Živa antika X, Skoplje 1960, 237-248.

\section{Tatić-Đurić 1964}

M. Tatić-Đurić, Zlatni nalaz iz Višnjice, Zbornik Narodnog muzeja IV, 1964, 185-195.

\section{Tatić-Đurić 1967}

M. Tatić-Đurić, Srebrno posuđe iz Kostolca, Zbornik Narodnog muzeja V, Beograd, 1967, 237-246.

\section{Teodor 2001}

D. Gh. Teodor, Christian Roman Byzantine Imports North of the Lower Danube, Inter-academica II-III, Les Travaux de la VI-ème et VII-ème Session Annuelle, (Cernăuți/1999 et Mangalia/Neptun/2000, Bucureşti 2001, 118-122.

\section{Валтровић 1886}

M. Валтровић, Старохришћански саркофаг нађен у Београду, Старинар III, Београд 1886, 7071.

\section{Валтровић 1891a}

M. Валтровић, Старохришћански мртвачки ковчег нађен у Београду, Старинар VIII, Београд 1891, 130-142.

\section{Валтровић 1891б}

М. Валтровић, Добри пастир, Старинар VIII, Београд 1891, 109-130.

\section{Zotović 1994}

Lj. Zotović, Rano hrišćanstvo u Viminacijumu kroz izvore i arheološke spomenike, Viminacium 8-9, Požarevac 1994, 59-72. 


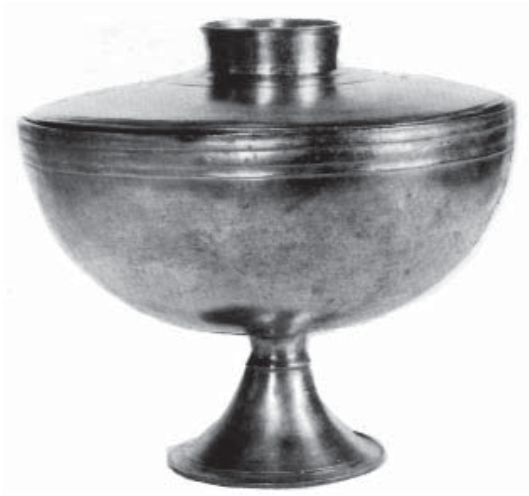

1

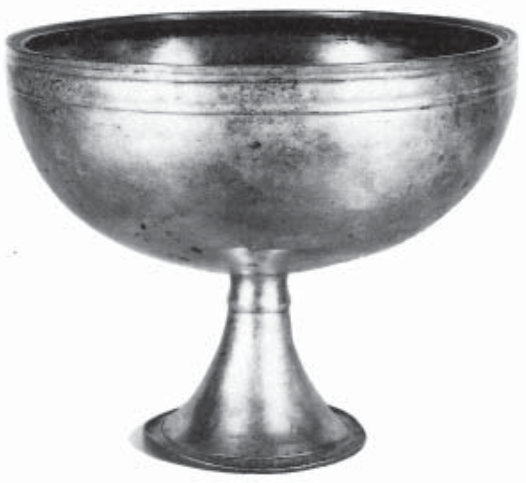

3

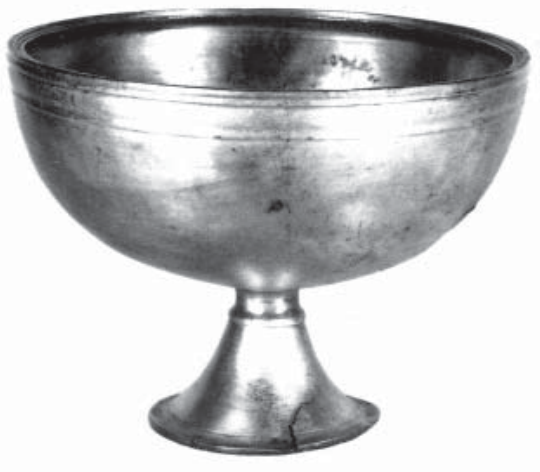

4

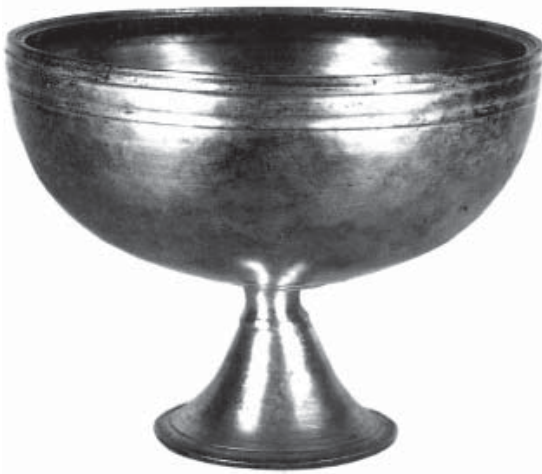

5

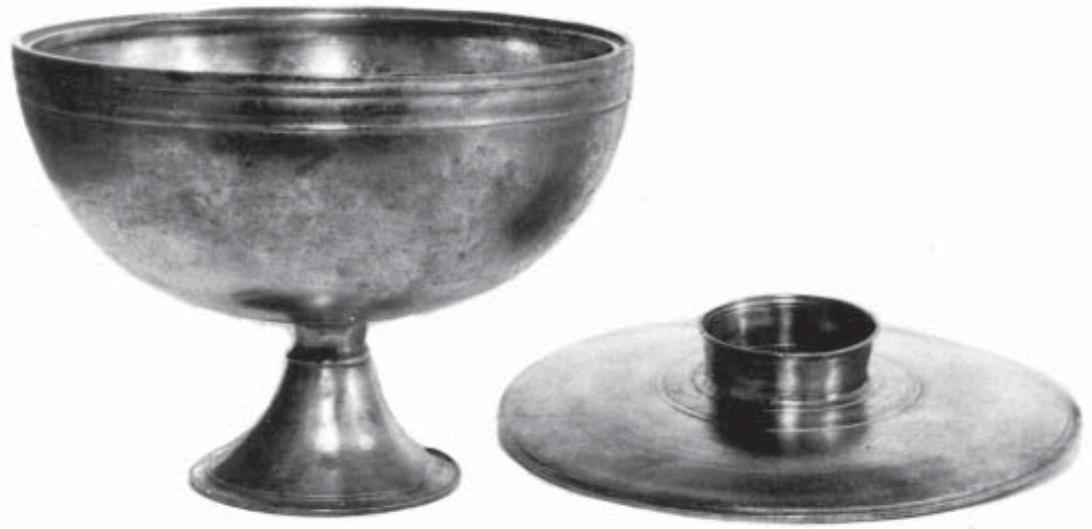

Slika I/1-5 - Ostava sa srebrnim peharima. Kostolac (Viminacium). 


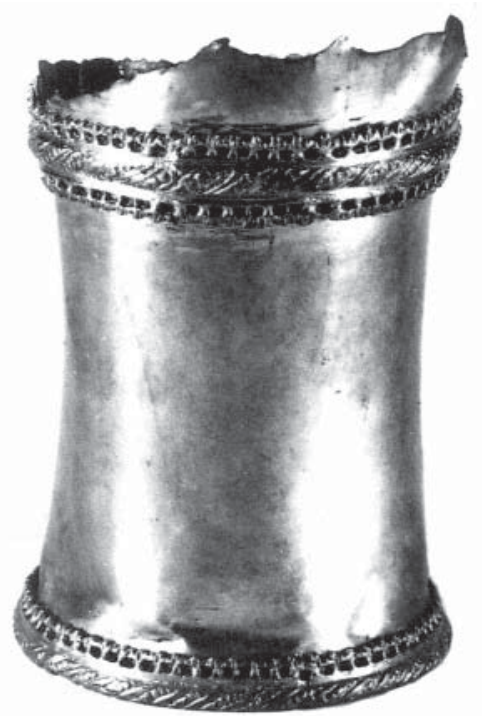

Slika II/1 - Stopa srebrnog pehara. Niš (Naissus)
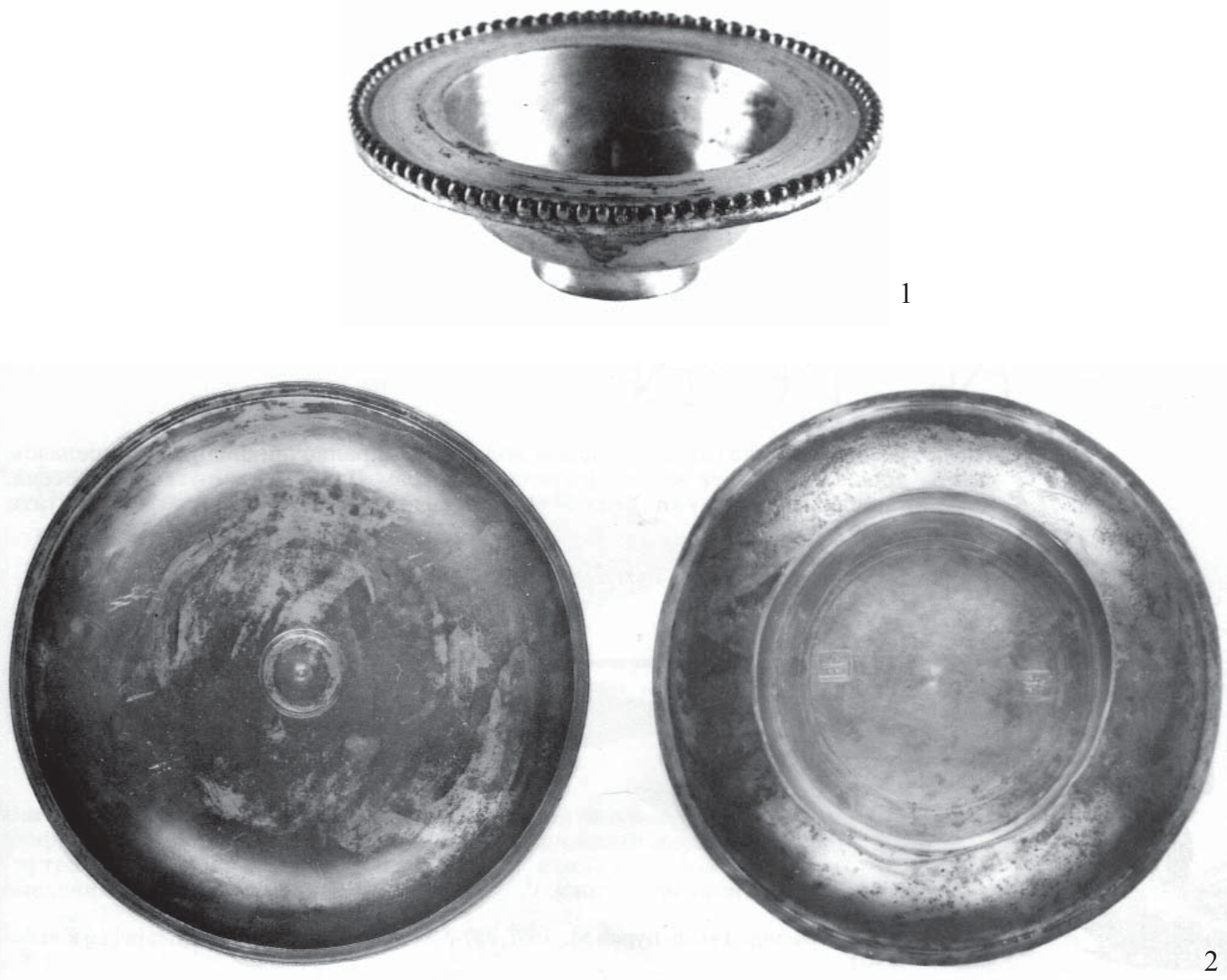

Slika III/1-2 - Srebrne zdele. Kostolac (Viminacium). 

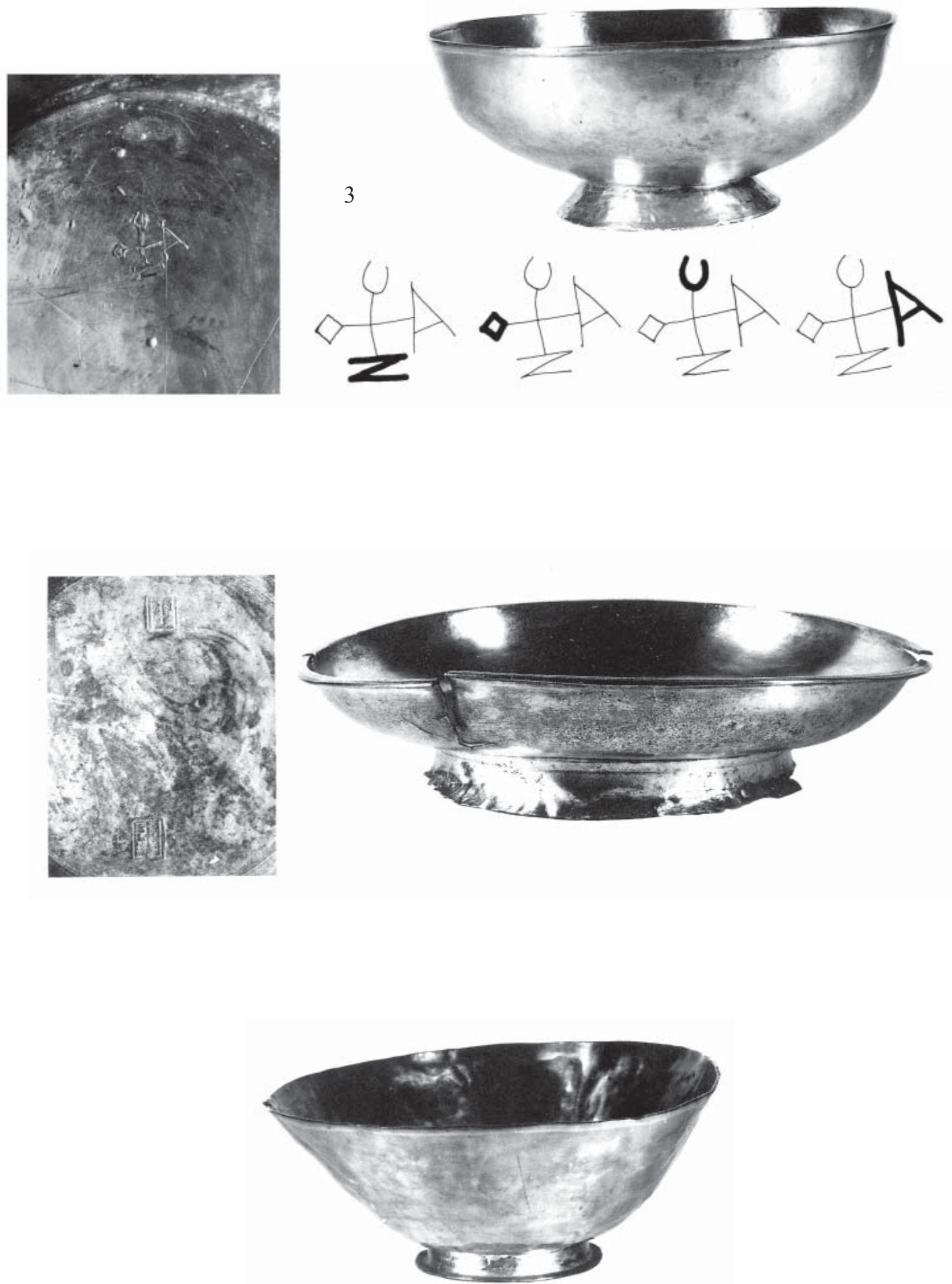

Slika III/3-5 - Srebrne zdele. Kostolac (Viminacium). 

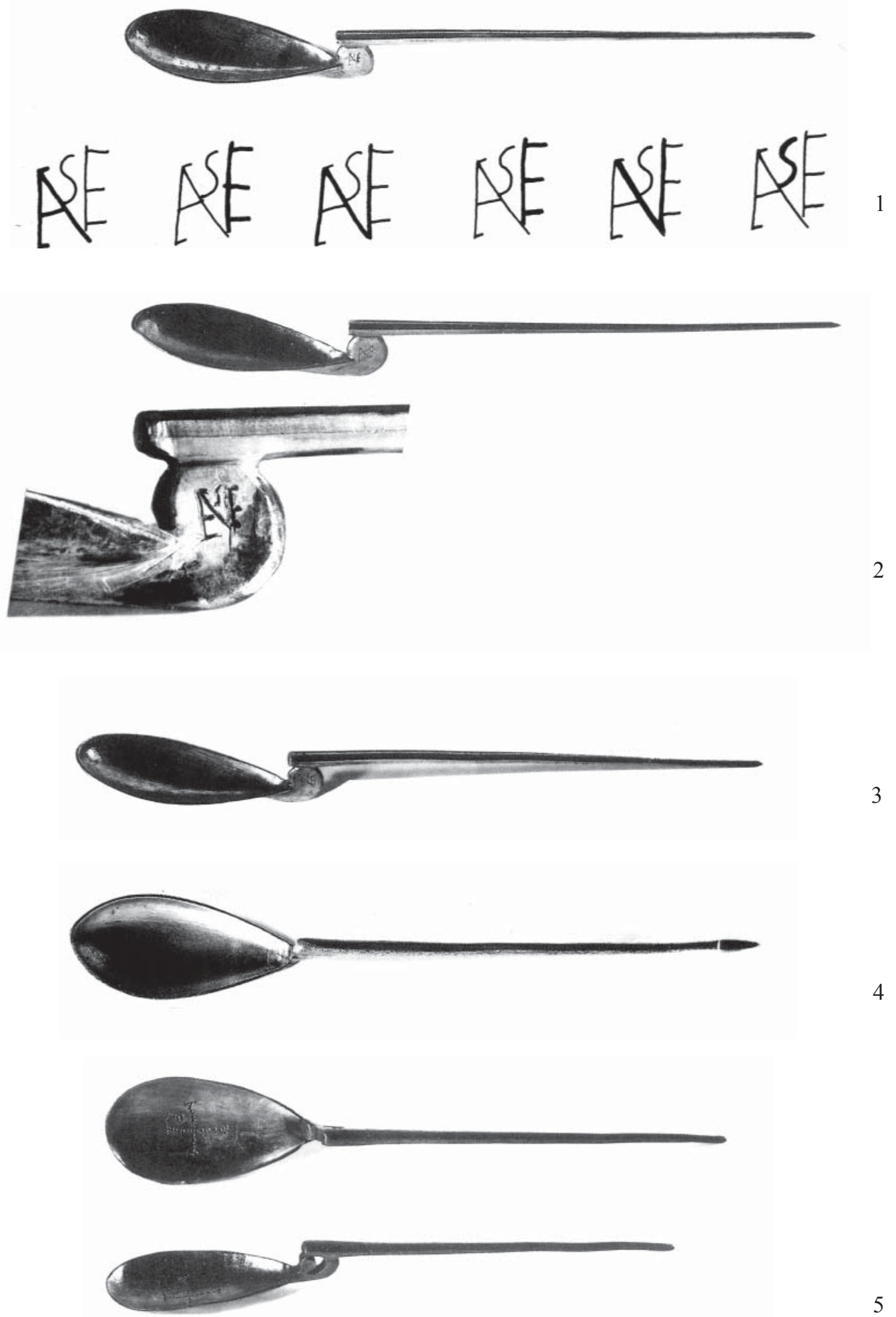

Slika IV/1-4 - Srebrne kašike. Kostolac (Viminacium). 5 - Srebrna kašika. Gamzigrad (Romuliana). 

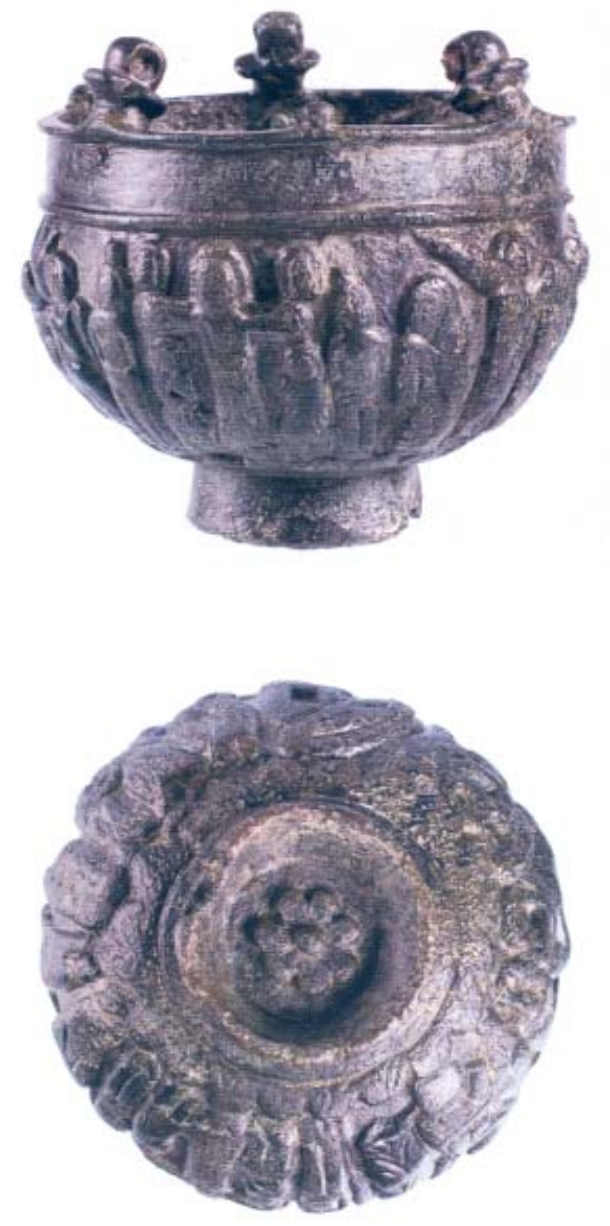

Slika V/1-2 - Kadionica. Pepeljevac, Kuršumlija.

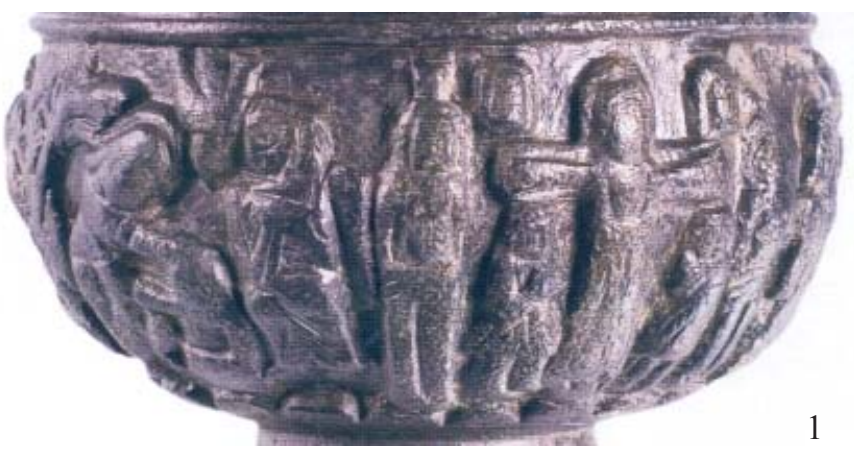

Slika VI/1 - Kadionica. Pepeljevac, Kuršumlija. Reljef. 

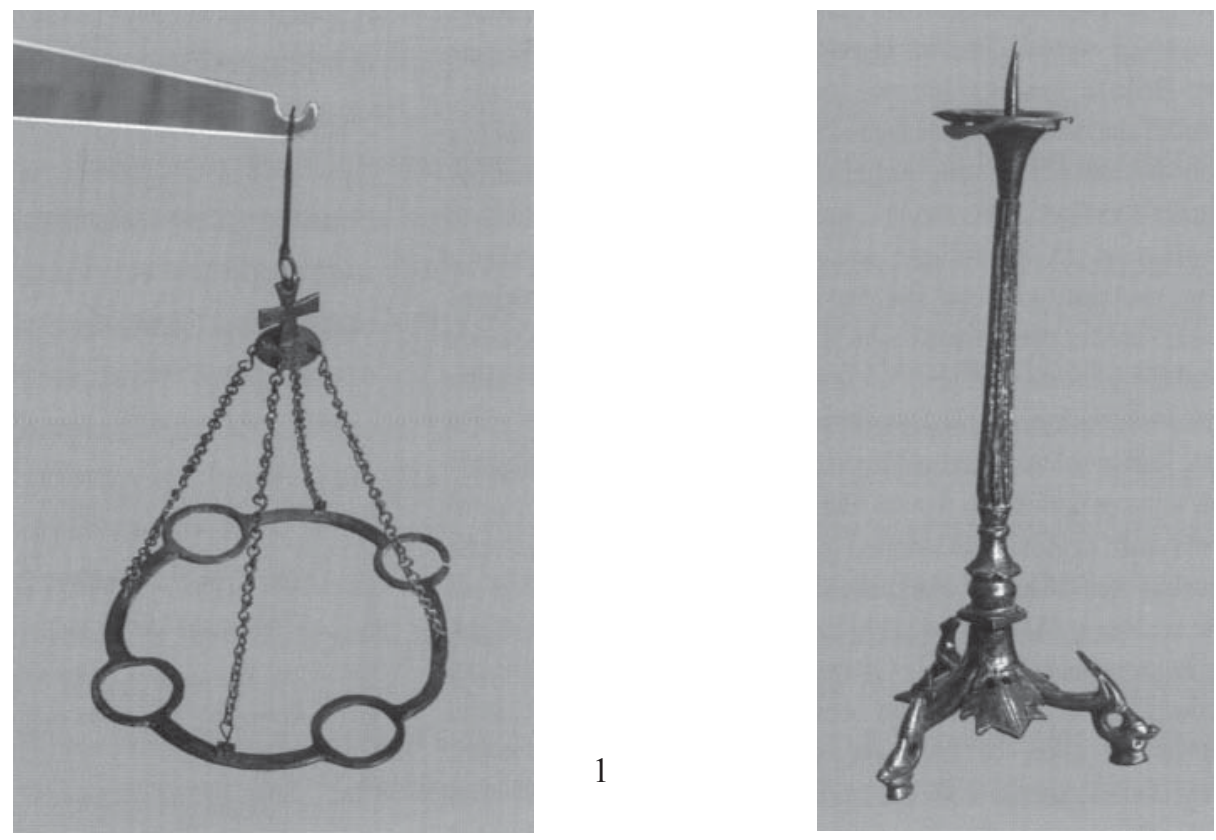

2
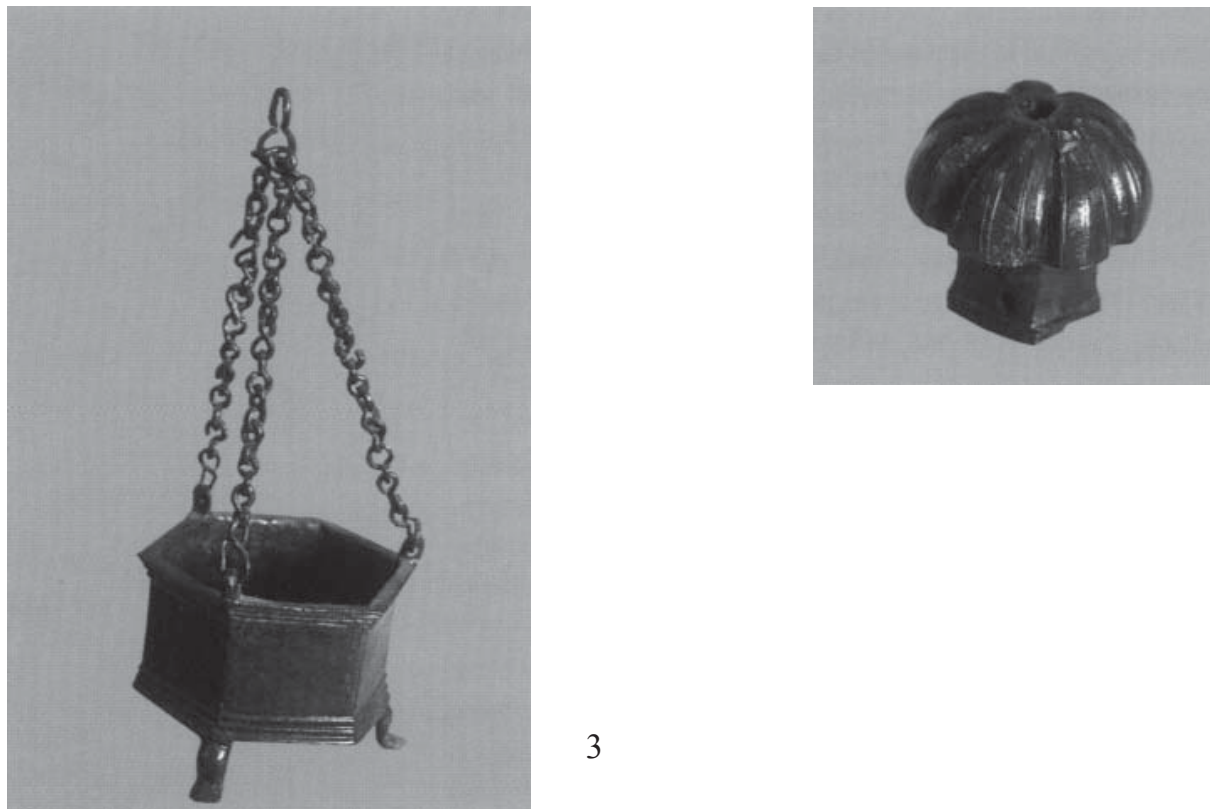

4

3

Slika VII/1-4 - Gamzigrad (Romuliana): Polikandilo, kandelabr, kadionica, okov u vidu pečurke. 


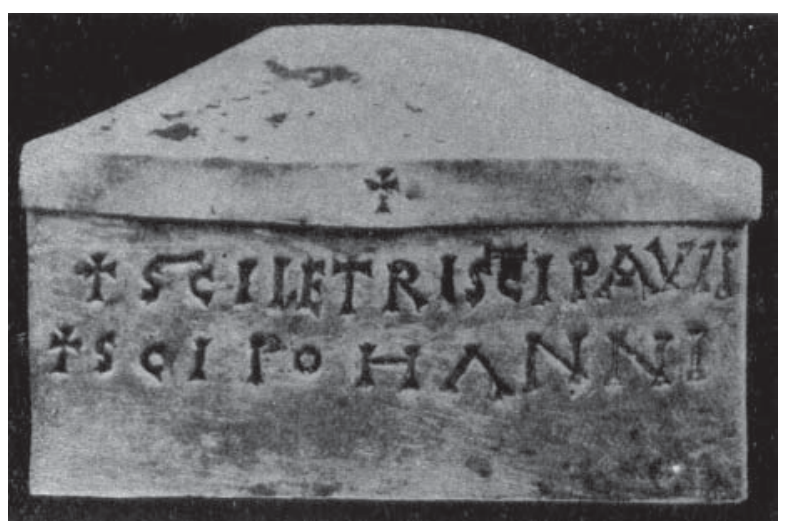

\section{1}
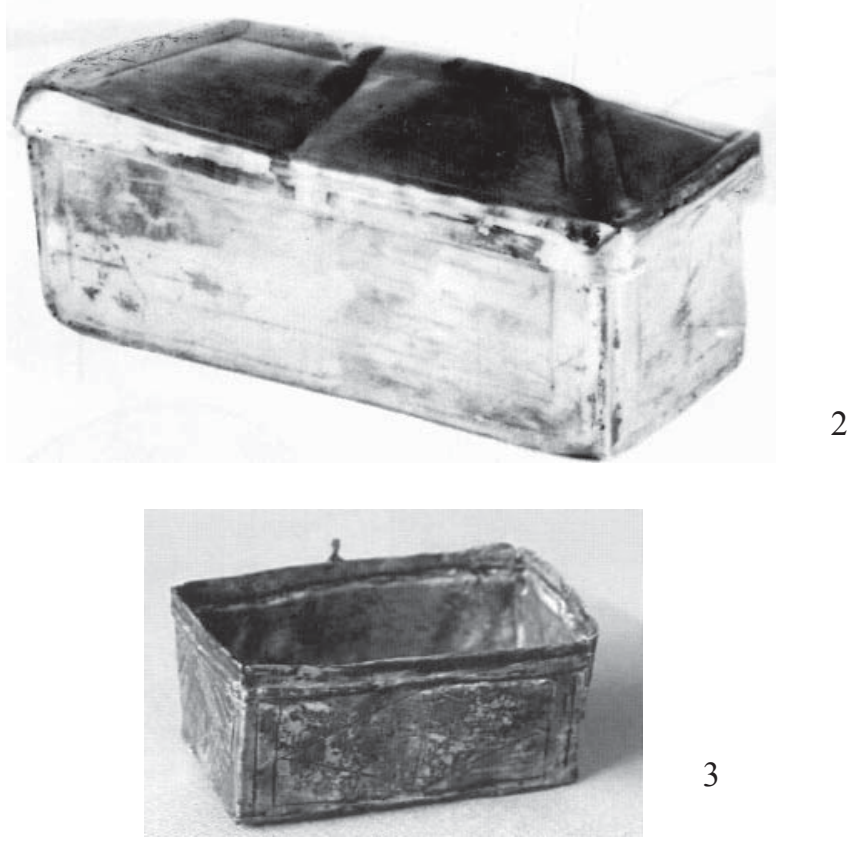

Slika VIII/1-3 Relikvijari: Gradina na Jelici, Niš (Naissus), Gamzigrad (Romuliana)
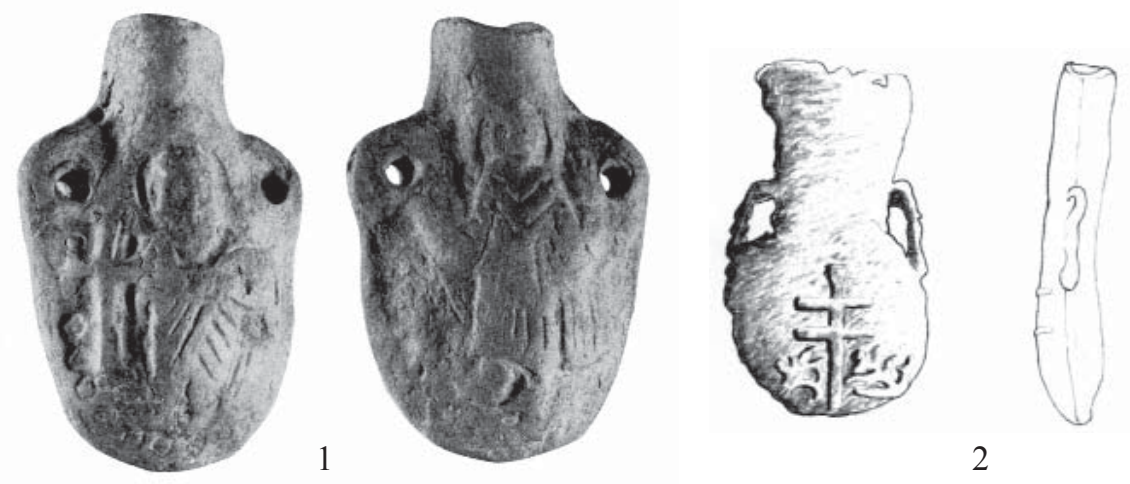

2

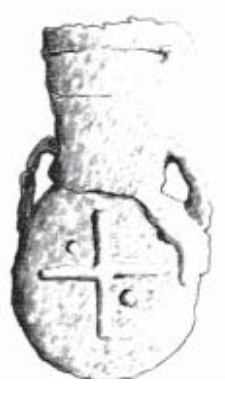

Slika IX/1-2 - Ampule. Caričin Grad (Iustiniana Prima). Mačvanska Mitrovica 

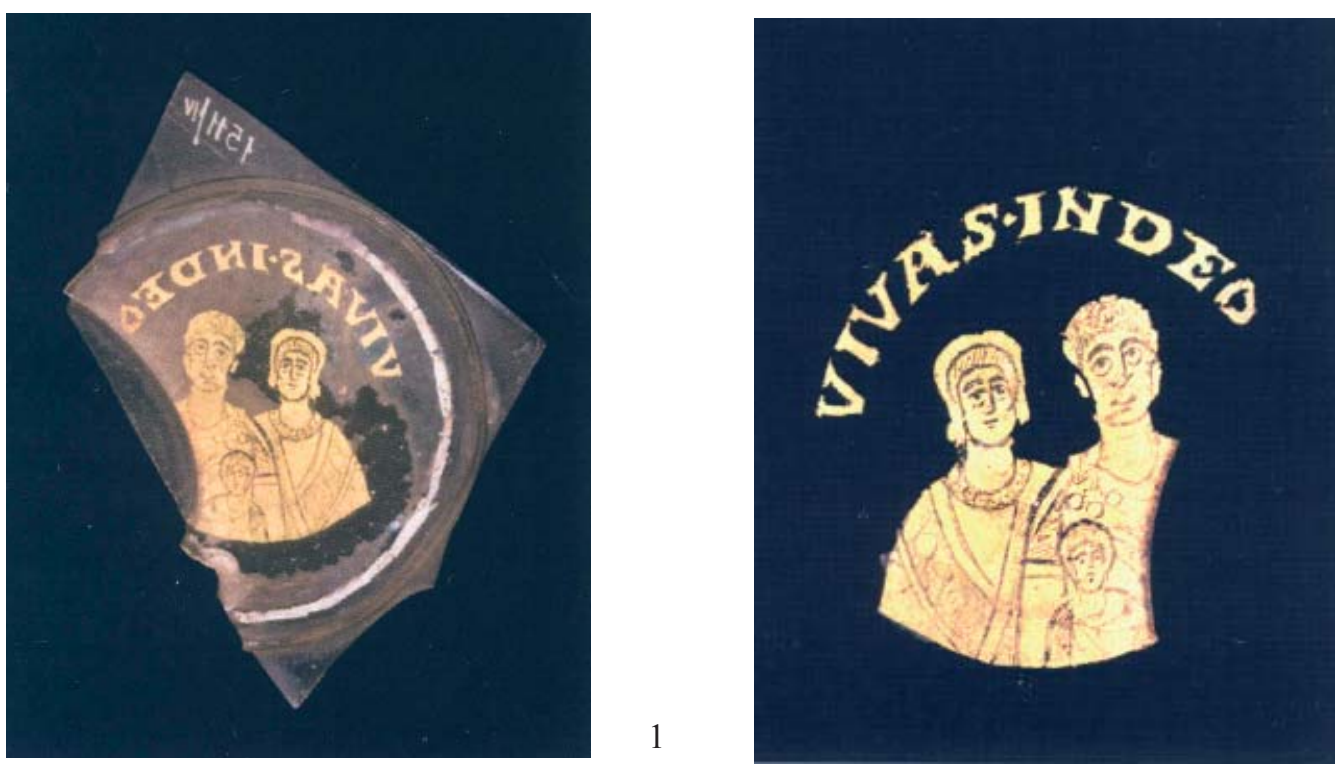

Slika X/1 a-b - Stakleno dno u tehnici fondi d'oro, Prahovo (Aquae)

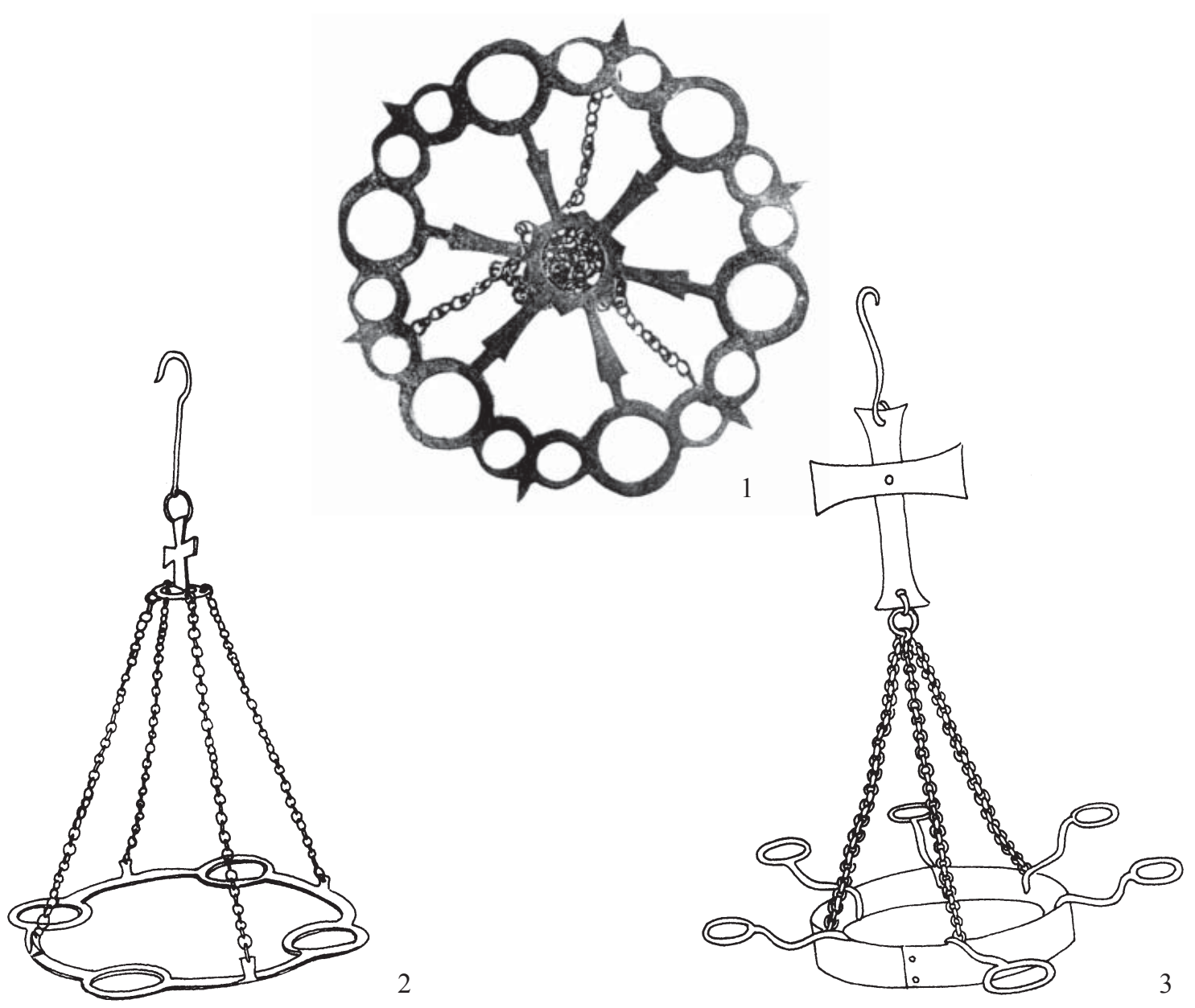

Slika XI/1-3 - Polikandila. Caričin Grad (Iustiniana Prima), Gamzigrad (Romuliana), Pirot. 

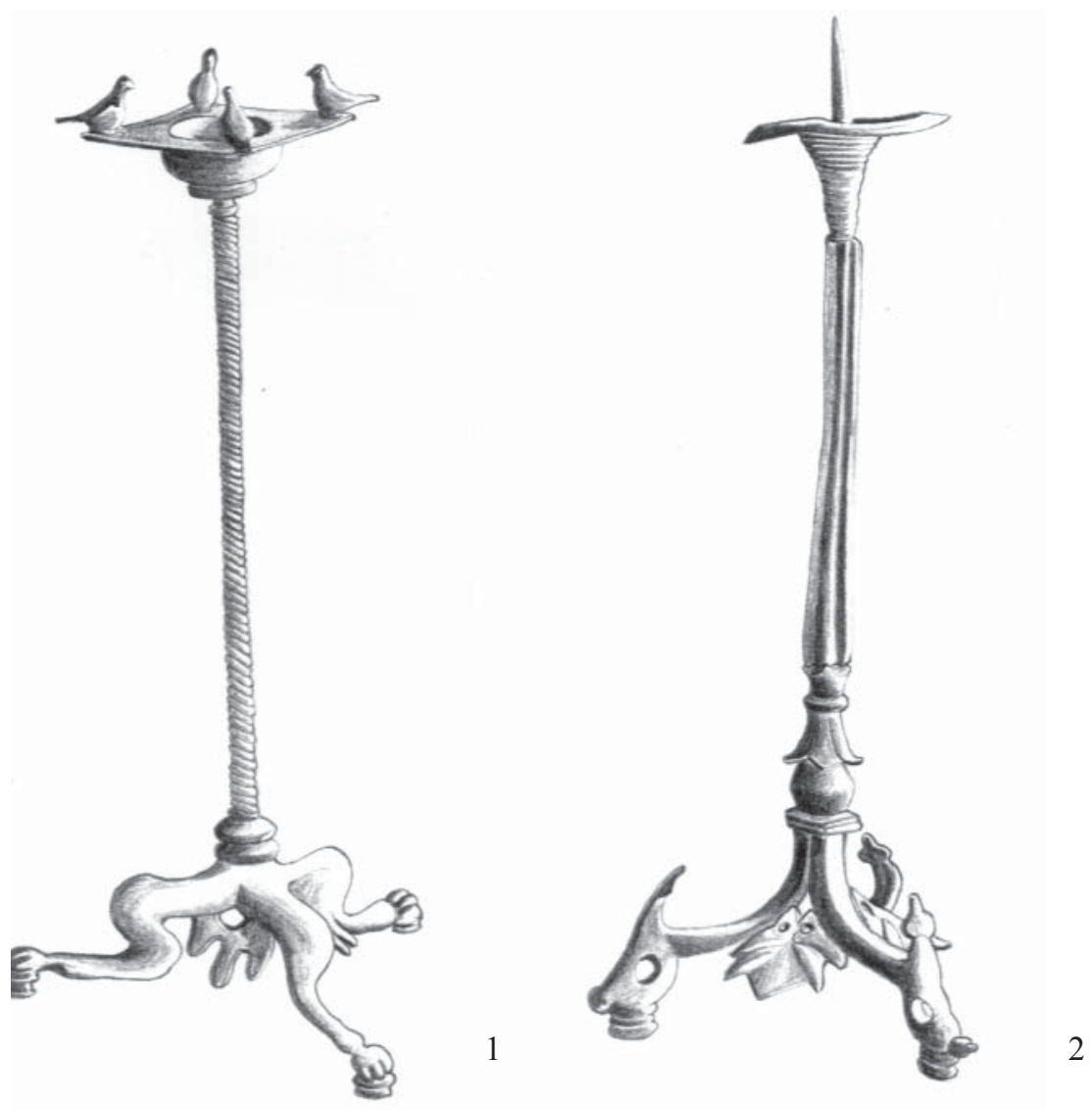

Slika XII/1-2 - Kandelabri. Nepoznato nalazište. Gamzigrad (Romuliana) 

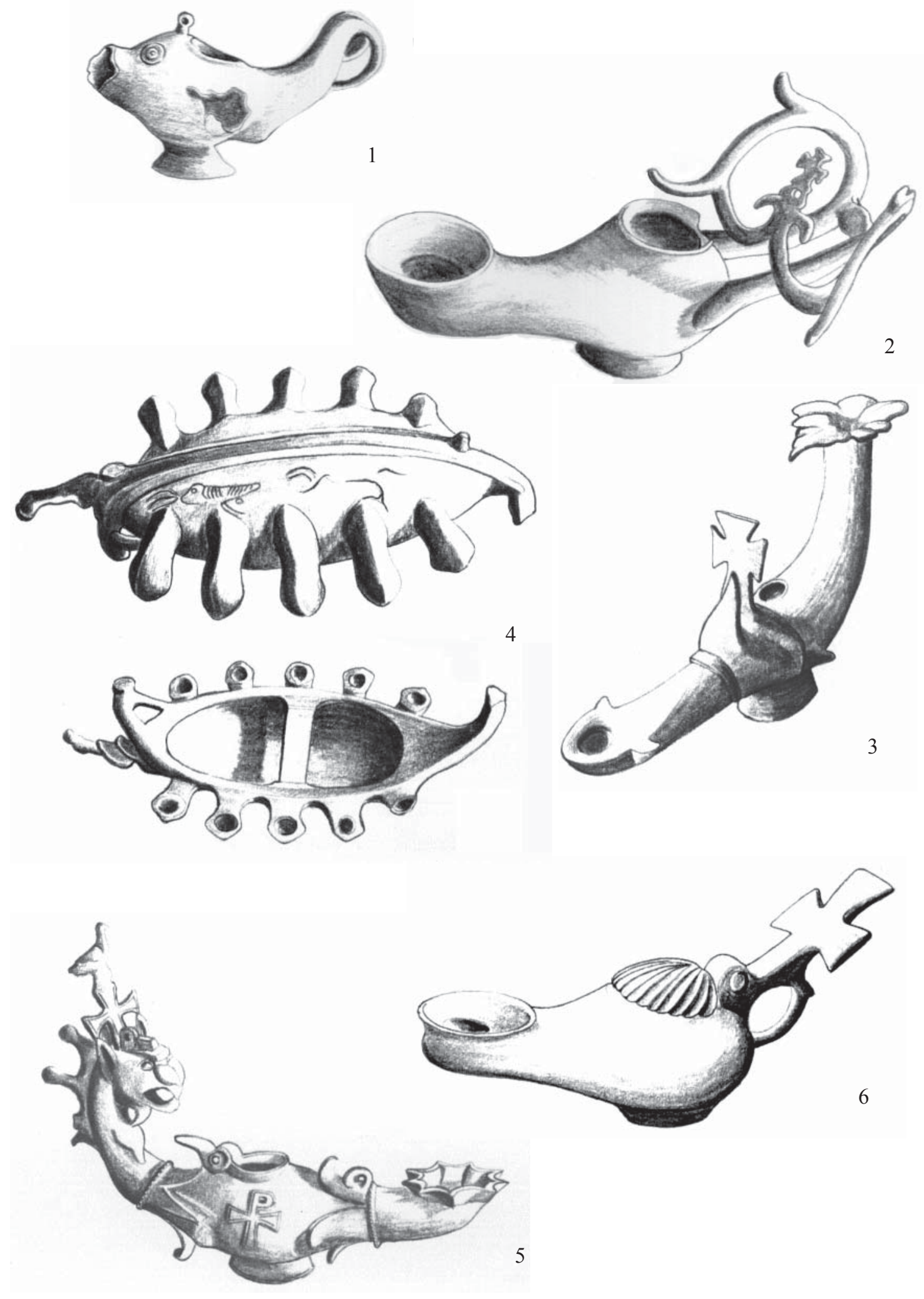

Slika XIII/1-6 - Lampe. 1 - Nepoznato nalazište. 2,3 - Kalaja Bujanovac. 4 - Mezul, Smederevo. 6. Despotovac. 6 Beograd 


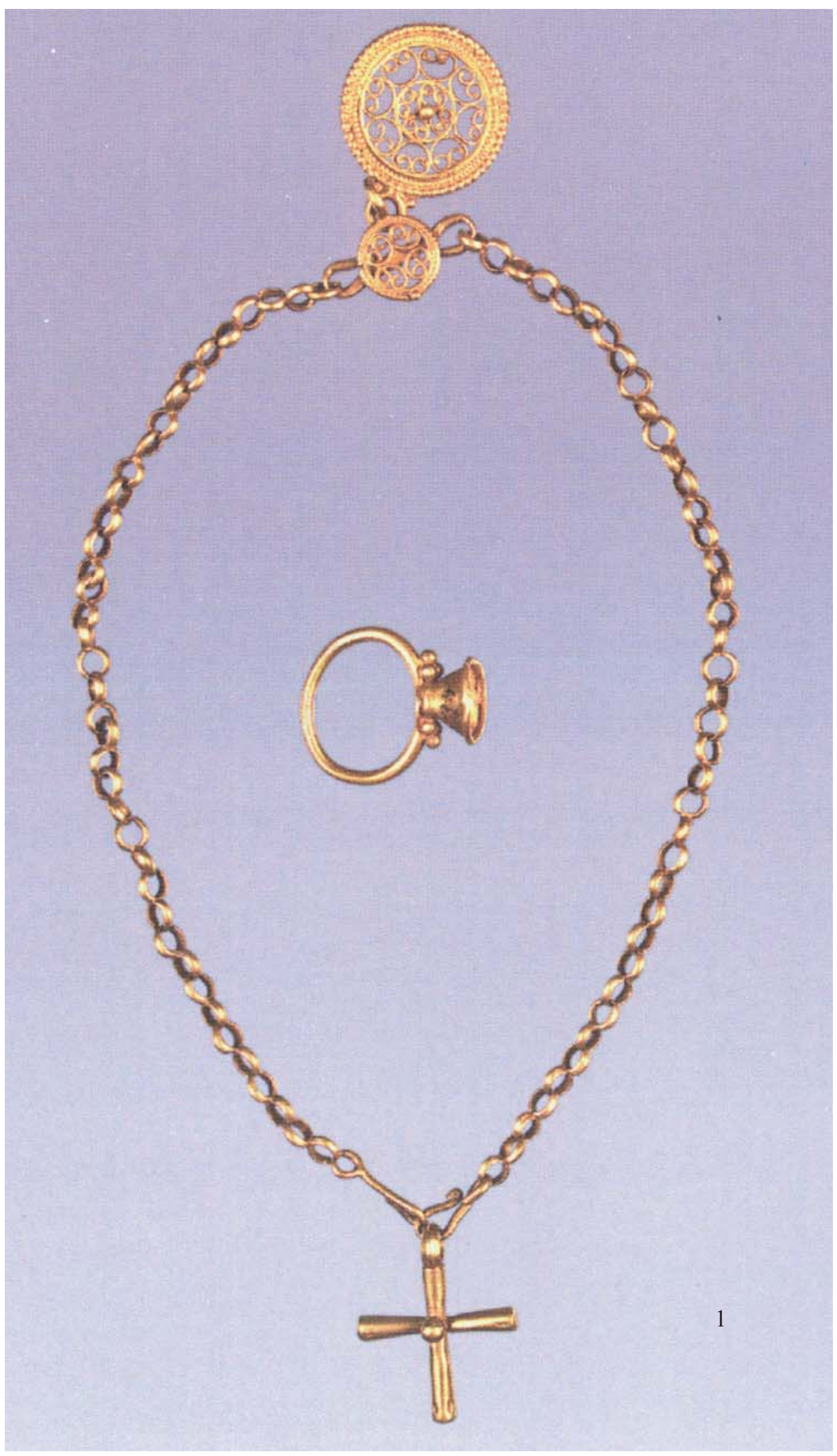

Slika XIV/1 - Nekropola Bela Stena, Beograd 